\title{
Phosphorylation and Feedback Regulation of Metabotropic Glutamate Receptor 1 by Calcium/Calmodulin-Dependent Protein Kinase II
}

\author{
Dao-Zhong Jin, ${ }^{1}$ Ming-Lei Guo, ${ }^{1}$ Bing Xue, ${ }^{1}$ Eugene E. Fibuch, ${ }^{2}$ Eun Sang Choe, ${ }^{1}$ Li-Min Mao, ${ }^{1}$ and John Q. Wang ${ }^{1,2}$ \\ Departments of ${ }^{1}$ Basic Medical Science and ${ }^{2}$ Anesthesiology, School of Medicine, University of Missouri-Kansas City, Kansas City, Missouri 64108
}

The metabotropic glutamate receptor $1(\mathrm{mGluR} 1)$ is a $\mathrm{G} \alpha_{\mathrm{q}}$-protein-coupled receptor and is distributed in broad regions of the mammalian brain. As a key element in excitatory synaptic transmission, the receptor regulates a wide range of cellular and synaptic activities. In addition to regulating its targets, the receptor itself is believed to be actively regulated by intracellular signals, although underlying

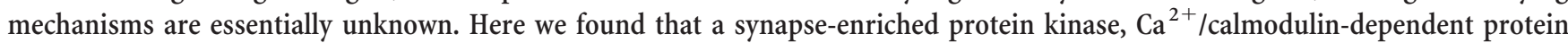
kinase II $\alpha(\mathrm{CaMKII} \alpha)$, directly binds to the intracellular $\mathrm{C}$ terminus (CT) of mGluR1a. This binding is augmented by $\mathrm{Ca}^{2+}$ in vitro. The direct interaction promotes CaMKII $\alpha$ to phosphorylate mGluR1a at a specific threonine site (T871). In rat striatal neurons, the mGluR1 agonist triggers the receptor-associated phosphoinositide signaling pathway to induce $\mathrm{Ca}^{2+}$-dependent recruitment of CaMKII $\alpha$ to mGluR1a-CT. This enables the kinase to inhibit the response of the receptor to subsequent agonist exposure. Our data identify an agonist-induced and $\mathrm{Ca}^{2+}$-dependent protein-protein interaction between a synaptic kinase and mGluR1, which constitutes a feedback loop facilitating desensitization of mGluR1a.

\section{Introduction}

L-Glutamate, a major neurotransmitter in the mammalian brain, interacts with both ionotropic and metabotropic glutamate receptors (mGluRs) to modulate a variety of cellular and synaptic activities (Traynelis et al., 2010). In the G-protein-coupled mGluR family, eight subtypes of mGluRs (mGluR1-mGluR8) have been cloned so far. Based on distinct pharmacological properties and postreceptor signaling, these mGluR subtypes have been classified into three functional groups (Niswender and Conn, 2010; Traynelis et al., 2010). Group I mGluRs, i.e., mGluR1 and mGluR5 subtypes, have drawn the most attention. As $\mathrm{G} \alpha$-coupled receptors, mGluR1/5 during activation stimulate phospholipase $\mathrm{C} \beta 1$ (PLC $\beta 1$ ) to hydrolyze a lipid signaling molecule, phosphoinositide (PI). This yields diacylglycerol (DAG), an activator of protein kinase C (PKC), and inositol1,4,5-triphosphate $\left(\mathrm{IP}_{3}\right)$, which releases $\mathrm{Ca}^{2+}$ from internal stores. Released $\mathrm{Ca}^{2+}$ ions could then trigger or modulate various downstream signaling pathways. Group I mGluRs are distributed in broad brain areas, including a key basal ganglia structure, the

Received July 5, 2012; revised Dec. 17, 2012; accepted Dec. 20, 2012.

Author contributions: D.-Z.J., L.-M.M., and J.Q.W. designed research; D.-Z.J., M.-L.G., and B.X. performed research; D.-Z.J., M.-L.G., B.X., E.E.F., E.S.C., L.-M.M., and J.Q.W. analyzed data; D.-Z.J., E.E.F., and J.Q.W. wrote the paper.

This work was supported by National Institutes of Health Grants DA10355 (J.Q.W.) and MH61469 (J.Q.W.) and by a grant from Saint Luke's Hospital Foundation.

The authors declare no competing financial interests.

Correspondence should be addressed to Dr. John Q. Wang, Department of Basic Medical Science, University of Missouri-Kansas City, School of Medicine, 2411 Holmes Street, Kansas City, M0 64108. E-mail: wangjq@umkc.edu.

E. S. Choe's present address: Department of Biological Sciences, Pusan National University, Pusan 609-735, Korea.

DOI:10.1523/JNEUROSCI.3192-12.2013

Copyright $\odot 2013$ the authors $\quad 0270-6474 / 13 / 333402-11 \$ 15.00 / 0$ striatum (Testa et al., 1994; Tallaksen-Greene et al., 1998). As such, these receptors actively regulate normal and abnormal synaptic activities related to motor, neuropsychiatric, neurodegenerative, and cognitive disorders (Traynelis et al., 2010; Nicoletti et al., 2011).

The mGluR1 is the first member of the mGluR family. Like typical G-protein-coupled receptors (GPCRs), mGluR1 is anchored in membranes by seven transmembrane helices. The intracellular $\mathrm{C}$ terminus (CT) is particularly large in the long-form splice variant $(1 \mathrm{a} ; 359 \mathrm{aa})$ relative to short-form variants $(1 \mathrm{~b}, 1 \mathrm{c}$, and $1 \mathrm{~d} ; 57-72 \mathrm{aa}$ ). This renders mGluRla a unique accessibility by various cytosolic binding partners (Enz, 2007, 2012; Fagni, 2012). Through CT interactions, these interacting partners scaffold the receptor at specific subcellular domains and modulate expression and signaling of the receptor (Enz, 2012; Fagni, 2012).

One modulation of mGluRla by interacting partners is phosphorylation. In this modification, a given protein kinase interacts with mGluRla CT and phosphorylates specific residue(s) to regulate mGluRla (for review, see Mao et al., 2011). $\mathrm{Ca}^{2+}$ / calmodulin-dependent protein kinase II (CaMKII) is a serine/ threonine kinase enriched at synaptic sites (Kennedy et al., 1983; Kelly et al., 1984). This kinase is activated by the binding of $\mathrm{Ca}^{2+}$ activated calmodulin (CaM). Active CaMKII then accesses and phosphorylates its specific substrates, while at the same time it catalyzes intersubunit autophosphorylation (T286 in the $\alpha$ isoform). Autophosphorylation sustains the $\mathrm{Ca}^{2+} / \mathrm{CaM}-$ independent (autonomous) activity even after the initial $\mathrm{Ca}^{2+}$ stimulus subsides (Miller and Kennedy, 1986; Hudmon and Schulman, 2002; Colbran and Brown, 2004; Griffith, 2004), by which CaMKII translates $\mathrm{Ca}^{2+}$ transients to the relatively prolonged regulation of its substrates. 
A

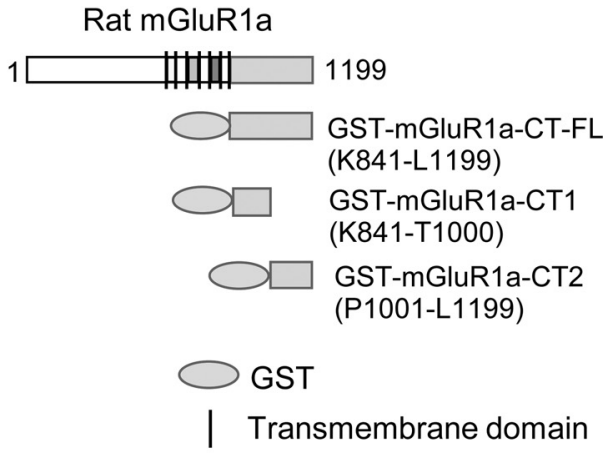

D

mGluR1a-CT1 (K841-T1000)

KPERNVRSAFTTSDVVRMHVGDGKLPCRSNTFI NIFRRKKPGAGNANSNGKSVSWSEPGGRQAPKG OHVWORLSVHVKTNETACNQTAVIKPLTKSYOG SGKSLTFSDASTKTLYNVEEEDNTPSAHFSPPS SPSMVVHRRGPPVATTPPLPPHLTAEET

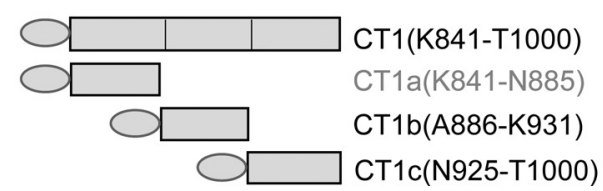

B

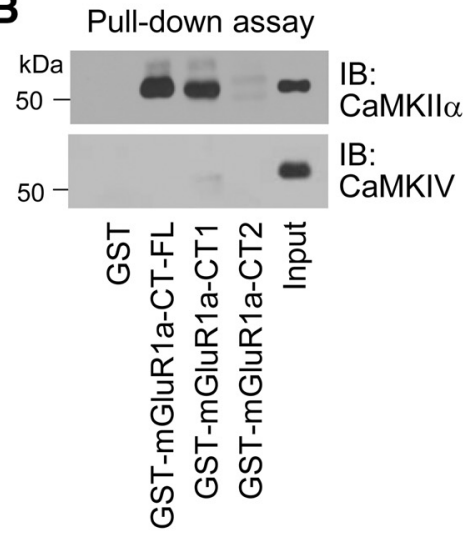

E

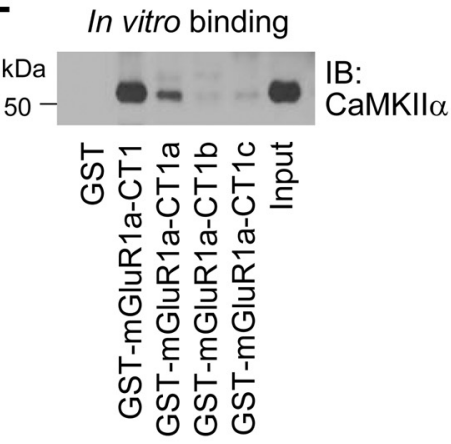

C

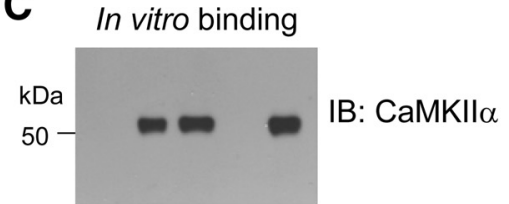

$\mathbf{F}$

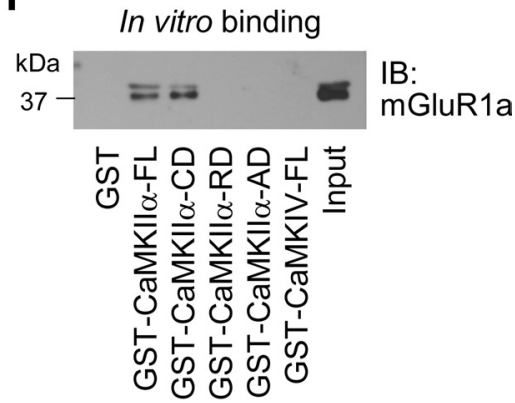

Figure 1. CaMKIl $\alpha$ binds to mGluR1a. A, GST-fusion proteins containing FL or fragments of (T of rat mGluR1a. $\boldsymbol{B}$, Pull-down assays with immobilized GST-fusion proteins and rat striatal lysates. Note that mGluR1a-CT-FL and CT1 but not CT2 pulled down CaMKII $\alpha$. The input was run alongside the pull-down samples and represents 2\% (CaMKII $\alpha$ ) or 4\% (CaMKIV) of total protein extract used in the assay. $\boldsymbol{C}$, In vitro binding assays with immobilized GST-fusion proteins and purified CaMKII $\alpha$. D, GST-fusion proteins containing different parts of mGluR1a-CT1. E, In vitro binding assays with immobilized mGluR1a-CT1 fragments and purified CaMKII $\alpha$. Note that CT1a, but not CT1b and CT1C, bound to CaMKII $\alpha$. $\boldsymbol{F}$, I vitro binding assays with immobilized GST-fusion proteins and purified mGluR1a-CT. GST-fusion proteins contain the CD, RD, or AD of CaMKIl $\alpha$ or CaMKIV. Proteins bound to GST-fusion proteins in either pull-down or binding assays were visualized with immunoblots (IB) using the specific antibodies as indicated. The input was $5 \%$ of total CaMKII $\alpha(\boldsymbol{C}, \boldsymbol{E})$ or mGluR1a-CT $(\boldsymbol{F})$ proteins used in in vitro binding assays.

CaMKII interacts with and regulates many synaptic targets (Colbran, 2004), although whether CaMKII interacts with mGluR1a is unknown. Here we found that CaMKII $\alpha$ directly binds to the proximal CT region of mGluRla. The binding is $\mathrm{Ca}^{2+}$ dependent and results in phosphorylation of mGluR1a at a specific CT site. Agonist activation of mGluRla in rat striatal neurons triggers a $\mathrm{Ca}^{2+}$-sensitive association of CaMKII $\alpha$ with mGluRla and promotes desensitization of the receptor. Together, we have discovered a negative feedback mechanism involving CaMKII-mGluRla interactions that controls desensitization of mGluRla.

\section{Materials and Methods}

Animals. Adult male Wistar rats weighting 200-350 g (Charles River) were individually housed at $23^{\circ} \mathrm{C}$ and humidity of $50 \pm 10 \%$ with food and water available ad libitum. The animal room was on a $12 \mathrm{~h}$ light/dark cycle with lights on at 7:00 A.M. All animal use procedures were in strict accordance with the National Institutes of Health Guide for the Care and Use of Laboratory Animals and were approved by the Institutional Animal Care and Use Committee.

Cloning, expression, and purification of glutathione S-transferase fusion proteins. Glutathione $S$-transferase (GST)-fusion proteins containing fulllength (FL) or truncated proteins of interest were synthesized as described previously (Liu et al., 2009; Guo et al., 2010). Briefly, the cDNA fragments encoding the mGluR1a-CT-FL(K841-L1199), mGluR1a-CT1(K841T1000), mGluR1a-CT2(P1001-L1199), mGluR1a-CT1a(K841-N885), mGluR1a-CT1b(A886-K931), mGluR1a-CT1c(N925-T1000), mGluR1a intracellular loop 1 [mGluR1a-IL1(R618-E629)], CaMKII $\alpha$ catalytic domain [CaMKII $\alpha-\mathrm{CD}(\mathrm{L} 91-\mathrm{S} 272)]$, CaMKII $\alpha$ regulatory domain
[CaMKII $\alpha-\mathrm{RD}(\mathrm{H} 273-\mathrm{S} 314)]$, CaMKII $\alpha$ association domain [CaMKII $\alpha-$ $\mathrm{AD}(\mathrm{G} 315-\mathrm{H} 478)]$, or GluA1-CT(E809-L889) were generated by PCR amplification from FL cDNA clones. These fragments were subcloned into BamHI-EcoRI sites of the pGEX4T-3 plasmid (GE Healthcare). Initiation methionine residues and stop codons were incorporated where appropriate. To confirm appropriate splice fusion, all constructs were sequenced. GSTfusion proteins were expressed in Escherichia coli BL21 cells (GE Healthcare) and purified from bacterial lysates as described by the manufacturer. GST- or His-tagged CaMKII $\alpha$-FL(M1-H478) and GST-tagged CaMKIV-FL(M1Y473) were expressed and purified via a baculovirus/Sf9 insect cell expression system.

Western blot analyses. Western blots were performed as described previously (Guo et al., 2010). Briefly, proteins were separated on SDS NuPAGE Bis-Tris $4-12 \%$ gels (Invitrogen) and were transferred to polyvinylidene fluoride membranes. Membranes were incubated with primary antibodies usually at 1:1000 overnight at $4^{\circ} \mathrm{C}$. This was followed by an incubation of secondary antibodies (1:2000). Immunoblots were developed with the enhanced chemiluminescence reagent (GE Healthcare).

Affinity purification (pull-down) assay. Solubilized striatal extracts (50-100 $\mu$ g of proteins) were diluted with $1 \times$ PBS/1\% Triton X-100 and incubated with $50 \%(\mathrm{v} / \mathrm{v})$ slurry of glutathione-Sepharose $4 \mathrm{~B}$ beads (GE Healthcare) saturated with GST alone or with a GST-fusion protein $(5-10 \mu \mathrm{g})$ at $4^{\circ} \mathrm{C}$ for $2 \mathrm{~h}$. Beads were washed four times with $1 \times \mathrm{PBS} / 1 \%$ Triton X-100. Bound proteins were eluted with $4 \times$ lithium dodecyl sulfate (LDS) loading buffer, resolved by SDS-PAGE, and immunoblotted with a specific antibody.

In vitro binding assay. His-tagged CaMKII $\alpha(\sim 57 \mathrm{kDa}, 17 \mathrm{ng})$ was equilibrated to binding buffer $(200 \mathrm{~mm} \mathrm{NaCl}, 0.2 \%$ Triton X-100, 0.1 
$\mathrm{mg} / \mathrm{ml} \mathrm{BSA}$, and $50 \mathrm{~mm}$ Tris, $\mathrm{pH}$ 7.5) with or without $0.5 \mathrm{~mm} \mathrm{CaCl}_{2}, 1 \mu \mathrm{M} \mathrm{CaM}$, or $1 \mathrm{~mm}$ EGTA as indicated. Binding reactions were initiated by adding purified GST-fusion proteins and were remained at $4^{\circ} \mathrm{C}$ for $2-3 \mathrm{~h}$. GSTfusion proteins were precipitated using $100 \mu \mathrm{l}$ of $10 \%$ glutathione-Sepharose $4 \mathrm{~B}$ beads. The precipitate was washed three times with binding buffer. Bound proteins were eluted with $4 \times$ LDS loading buffer, resolved by SDSPAGE, and immunoblotted with a specific antibody.

Coimmunoprecipitation. Rats were anesthetized and decapitated. Brains were removed, and coronal sections were cut. The striatum was removed and homogenized on ice in the homogenization buffer containing $0.32 \mathrm{M} \mathrm{su}$ crose, 10 mm HEPES, pH 7.4, 2 mm EDTA, a protease inhibitor cocktail (Thermo Fisher Scientific), and a phosphatase inhibitor cocktail (Thermo Fisher Scientific). Homogenates were centrifuged at $760 \times g$ for $10 \mathrm{~min}$ at $4^{\circ} \mathrm{C}$. The supernatant was centrifuged at $10,000 \times g$ at $4^{\circ} \mathrm{C}$ for 30 min to obtain P2 pellets (synaptosomal fraction). P2 pellets were solubilized in the homogenization buffer containing $1 \%$ sodium deoxycholate for $1 \mathrm{~h}$ at $4^{\circ} \mathrm{C}$. Solubilized proteins $(150 \mu \mathrm{g})$ were incubated with a rabbit antibody against CaMKII $\alpha$ or mGluRla. The complex was precipitated with $50 \%$ protein $\mathrm{A}$ or G agarose/Sepharose bead slurry (GE Healthcare). Proteins were separated on Novex $4-12 \%$ gels and probed with a mouse antibody against CaMKII $\alpha$ or mGluR1a. HRP-conjugated secondary antibodies and enhanced chemiluminescence were used to visualize proteins.

Phosphorylation reactions in vitro. GST, GST-fusion proteins, or synthetic peptides were incubated with CaMKII $\alpha$ or protein kinase A (PKA) (Millipore) for $30 \mathrm{~min}$ or indicated durations at $30^{\circ} \mathrm{C}$ in a volume of $25 \mu \mathrm{l}$ of the reaction buffer containing $10 \mathrm{~mm}$ HEPES, pH 7.4, $10 \mathrm{~mm} \mathrm{MgCl}_{2}, 1 \mathrm{~mm} \mathrm{Na} \mathrm{VO}_{4}, 1 \mathrm{~mm}$ DTT, $0.1 \mathrm{mg} / \mathrm{ml} \mathrm{BSA}, 50 \mu \mathrm{M}$ ATP, and $2.5 \mu \mathrm{Ci} /$ tube $\left[\gamma^{-}{ }^{32} \mathrm{P}\right]$ ATP $(\sim 3000 \mathrm{Ci} / \mathrm{mmol}$; PerkinElmer Life and Analytical Sciences) with or without $0.5 \mathrm{~mm} \mathrm{CaCl}_{2}$ and $1 \mu \mathrm{M}$ CaM. The phosphorylation reactions were stopped by adding LDS sample buffer and boiling for 3 min. Phosphorylated proteins were resolved by SDS-PAGE and visualized by autoradiography.

Autophosphorylation of CaMKII $\alpha$. Autophosphorylation reactions were performed in $25 \mu \mathrm{l}$ of reaction buffer containing $500 \mathrm{ng}$ of CaMKII $\alpha$, 50 mm PIPES, pH 7.0, $10 \mathrm{~mm} \mathrm{MgCl}_{2}, 0.1 \mathrm{mg} / \mathrm{ml} \mathrm{BSA}, 0.5 \mathrm{~mm}$ $\mathrm{CaCl}_{2}, 50 \mu \mathrm{M} \mathrm{ATP}$, and $1 \mu \mathrm{M} \mathrm{CaM}$ for $10 \mathrm{~min}$ at $30^{\circ} \mathrm{C}$. The reaction was stopped by adding EGTA ( $5 \mathrm{~mm}$ final concentration) on ice. Aliquots ( 5 $\mu \mathrm{l})$ of the autophosphorylated kinases were immediately used in in vitro binding assays.

Dephosphorylation with calf-intestinal alkaline phosphatase. For dephosphorylation of phosphorylated GST-fusion proteins, proteins were incubated with active CaMKII $\alpha$ (100 ng) in $25 \mu$ reaction buffer containing 10 mм HEPES pH 7.4, $10 \mathrm{~mm} \mathrm{MgCl}_{2}, 1 \mathrm{~mm} \mathrm{Na}_{3} \mathrm{VO}_{4}, 1 \mathrm{~mm}$ DTT, $50 \mu \mathrm{M}$ ATP, and $2.5 \mu \mathrm{Ci} /$ tube $\left[\gamma^{-}{ }^{32} \mathrm{P}\right] \mathrm{ATP}(\sim 3000 \mathrm{Ci} / \mathrm{mmol}$, PerkinElmer). After $30 \mathrm{~min}$ at $30^{\circ} \mathrm{C}$, GST-fusion proteins were precipitated and the supernatant containing CaMKII $\alpha$ was removed. Precipitates were washed twice. They were then suspended in a solution containing calfintestinal alkaline phosphatase (CIP) $(100 \mathrm{U} / \mathrm{ml}$; Roche) and incubated for $1 \mathrm{~h}$ at $37^{\circ} \mathrm{C}$. Samples were then subjected to standard gel electrophoresis and autoradiography. CaMKIll $\alpha(C)$.
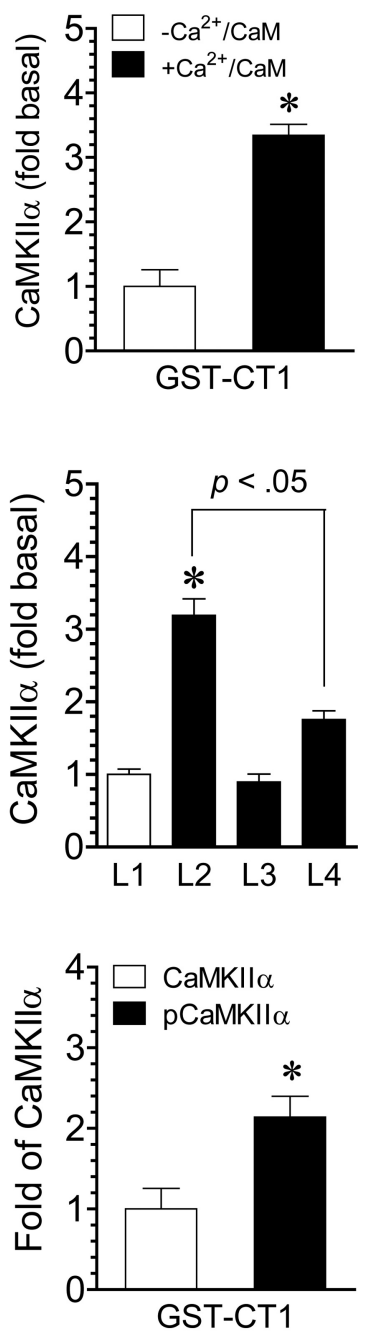

Figure 2. $\mathrm{Ca}^{2+} / \mathrm{CaM}$ and T286-autophosphorylation potentiate CaMKII $\alpha$ binding to mGluR1a. $\boldsymbol{A}, \mathrm{Ca}^{2+} / \mathrm{CaM}^{2}$ increased the binding of CaMKII $\alpha$ to mGluR1a-CT1. B, The inhibitory peptide (L290-A309) reduced the $\mathrm{Ca}^{2+} / \mathrm{CaM}$-induced potentiation of CaMKII $\alpha$-mGluR1a binding. C, T286-autophosphorylated CaMKIl $\alpha$ showed a higher level of binding to mGluR1a-CT1 compared in quantified data. Data are presented as means \pm SEM $\left(n=3-5\right.$ per group). ${ }^{*} p<0.05$ versus $\mathrm{Ca}^{2+} / \mathrm{CaM}$-free samples $(\boldsymbol{A}, \boldsymbol{B})$ or

$I P_{3}$ assays. The intracellular level of $\mathrm{IP}_{3}$ was measured using a HitHunter IP ${ }_{3}$ Fluorescence Polarization Assay Kit from DiscoveRx according to the protocol of the manufacturer. The assay is a competitive binding analysis and is a rapid and direct measurement of cellular $\mathrm{IP}_{3}$. In the assay, cellular $\mathrm{IP}_{3}$ displaces a fluorescent derivative of $\mathrm{IP}_{3}$ (tracer) from a specific binding protein, which reduces the amount of bound $\mathrm{IP}_{3}$ tracers and lowers fluorescence polarization signals. Rat striatal slices were lysed by perchloric acid after drug treatment. Cell lysates or $\mathrm{IP}_{3}$ standards were pipetted into a 96-well plate. The $\mathrm{IP}_{3}$ tracer $(20 \mu \mathrm{l})$ was added into each well. After shaking ( $5 \mathrm{~min}$ ), the $\mathrm{IP}_{3}$ binding protein $(40$ $\mu \mathrm{l})$ was added. The fluorescence polarization of the $\mathrm{IP}_{3}$ tracer (fluorescein) was detected in a BioTek Synergy 2 multi-detection microplate reader with a fluorescence polarization filter, using the $485 \mathrm{~nm}$ excitation wavelength and $530 \mathrm{~nm}$ emission wavelength. The $\mathrm{IP}_{3}$ concentration of each sample was calculated from the plotted standard curve.

Striatal slice preparation. Striatal slices were prepared as described previously (Liu et al., 2009). Briefly, rats were decapitated after anesthesia, and brains were removed and placed in ice-cold artificial CSF (ACSF) containing (in mM) 10 glucose, $124 \mathrm{NaCl}, 3 \mathrm{KCl}, 1.25 \mathrm{KH}_{2} \mathrm{PO}_{4}, 26$ 
A

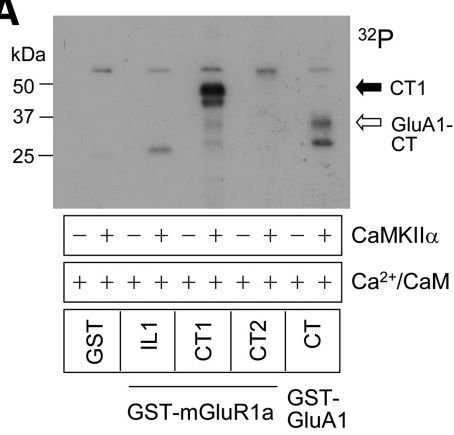

B

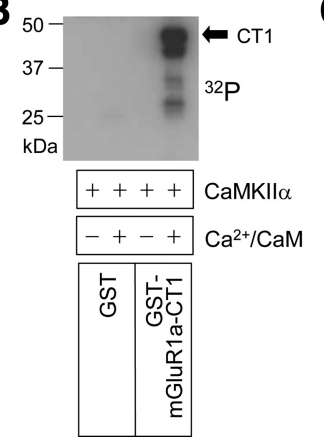

Figure 3. Phosphorylation of mGluR1a by CaMKIl $\alpha$. A, An autoradiograph illustrating phosphorylation of GST-mGluR1a-CT1, but not GST, GST-mGluR1a-IL1, and GST-mGluR1a-CT2, in the presence of $\mathrm{Ca}^{2+} / \mathrm{CaM}$. B, An autoradiograph illustrating phosphorylation of GST-mGluR1a-CT1 in the presence but not absence of $\mathrm{Ca}^{2+} / \mathrm{CaM}$. C, An autoradiograph illustrating phosphorylation of GST-mGluR1a-CT1 in the presence but not absence of ATP. Phosphorylation reactions were performed at $30^{\circ} \mathrm{C}$ for $30 \mathrm{~min}$ with or without $\left[\gamma^{-}{ }^{32}\right.$ P]ATP. The reactions were then subjected to gel electrophoresis, followed by autoradiography. Filled and open arrows indicate phosphorylated GST-mGluR1a-CT1 and GST-GluA1-CT, respectively.

$\mathrm{NaHCO}_{3}, 2 \mathrm{MgSO}_{4}$, and $2 \mathrm{CaCl}_{2}$, bubbled with $95 \% \mathrm{O}_{2}-5 \% \mathrm{CO}_{2}$, pH 7.4. Coronal slices were prepared using a vibratome (VT1200S; Leica). The striatum was dissected from the slices in ice-cold ACSF. Slices were preincubated in ACSF in an incubation tube at $30^{\circ} \mathrm{C}$ under constant oxygenation with $95 \% \mathrm{O}_{2}-5 \% \mathrm{CO}_{2}$ for $60 \mathrm{~min}$. The solution was replaced with fresh ACSF for an additional preincubation (10-20 min). Drugs as specified in each experiment were added and incubated at $30^{\circ} \mathrm{C}$. After drug treatment, slices were frozen and stored at $-80^{\circ} \mathrm{C}$ until assayed.

Peptide synthesis. Peptides, including Tat-fusion peptides, were synthesized and purified by Peptide 2.0 (Chantilly, VA). Tat-fusion peptides gain cell permeability by containing an arginine-enriched cellmembrane transduction domain of the human immunodeficiency virus type 1 Tat protein (YGRKKRRQRRR) (Schwarze et al., 1999). The CaMKII inhibitory peptide, CaMKIINtide (KRPPKLGQIGRSKRVVIEDDR) derived from the CaMKII inhibitory protein CaMKIIN (Chang et al., 1998), was synthesized to contain a Tat domain (Vest et al., 2007). Kemptide (LRRASLG; Kemp et al., 1977) was purchased from ANAspec.

Antibodies and pharmacological agents. Antibodies used in this study include a rabbit antibody against mGluRla (1:1000; Millipore), CaMKII $\alpha$ (1: 1000; Santa Cruz Biotechnology), pCaMKII $\alpha$ (T286) (1:1000; Cell Signaling Technology), or GST (1:1000; Sigma), or a mouse antibody against mGluRla (1:1000; BD Biosciences), or CaMKII $\alpha$ (1:1000; Santa Cruz Biotechnology), or a goat antibody against CaMKIV (1:1000; Santa Cruz Biotechnology). Pharmacological agents, including (RS)-3,5-dihydroxyphenylglycine (DHPG), 3-methyl-aminothiophene dicarboxylic acid (3-MATIDA), and 3-((2-methyl-1,3-thiazol-4-yl)ethynyl)pyridine hydrochloride (MTEP) were purchased from Tocris Cookson. Ionomycin, KN93 (2-[N-(2-hydroxyethyl)]- $N$-(4-methoxybenzenesulfonyl) amino- $N$-(4-chlorocinnamyl)- $N$-methylbenzylamine), and KN92 (2-[N-(4-methoxybenzenesulfonyl)] amino- $N$-(4-chlorophenyl)-2-propenyl- $N$-methylbenzylamine phosphate) were purchased from Sigma. All drugs were freshly prepared at the day of experiments.

Statistics. The results are presented as means \pm SEM and were evaluated using a one- or two-way ANOVA, as appropriate, followed by a Bonferroni's (Dunn's) comparison of groups using least-squaresadjusted means. Probability levels of $<0.05$ were considered statistically significant.

\section{Results}

\section{CaMKII $\alpha$ binds to the C-terminal region of mGluR1a}

We first explored possible protein-protein interactions between CaMKII $\alpha$ and mGluRla. We focused on the CT domain of mGluRla because it is much larger than other intracellular domains. GST-fusion proteins containing FL or fragments of mGluR1a-CT were synthesized (Fig. 1A). Using these immobilized baits in pull-down assays, we found that GST-mGluR1aCT-FL(K841-L1199) pulled down CaMKII $\alpha$ from soluble rat
$\mathbf{C}_{50-10}$

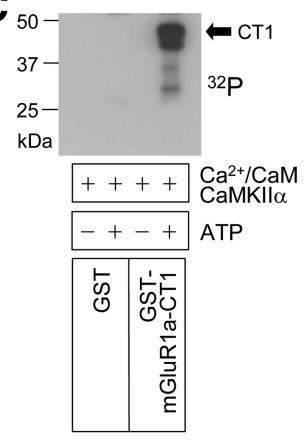

striatal lysates (Fig. 1B). The N-terminal fragment of CT, GST-mGluRlaCT1(K841-T1000), also pulled down CaMKII $\alpha$, whereas GST alone and the C-terminal fragment of CT, GSTmGluR1a-CT2(P1001-L1199), did not. No GST-fusion proteins pulled down CaMKIV (Fig. 1B). These data indicate that CaMKII $\alpha$ interacts with mGluRlaCT1. To determine whether CaMKII $\alpha$ directly binds to mGluRla, we performed binding assays with purified proteins. We found that purified CaMKII $\alpha$ bound to immobilized GST-mGluRla-CT-FL and GST-mGluR1a-CT1 but not GSTmGluR1a-CT2 or GST alone (Fig. 1C). Thus, CaMKII $\alpha$ can directly interact with the CT1 region of mGluR1a-CT. To further identify the CaMKII $\alpha$-binding region in the CT1 segment, we generated GST-fusion proteins containing different parts of CT1 (CT1aCT1c; Fig. 1D). CT1a(K841-N885) harbored the binding of CaMKII $\alpha$ (Fig. 1E). CT1b(A886-K931) and CT1c(N925T1000) did not (Fig. 1E). Thus, the CaMKII $\alpha$-binding site seems to locate in the CT1a region that contains the first 45 aa of mGluR1a-CT. All blots were probed in parallel with a GST antibody to ensure equivalent protein loading (data not shown).

We also tried to identify the CaMKII $\alpha$ region specific for the interaction with mGluRla. To this end, we prepared GST-fusion proteins containing distinct subdomains of the kinase. We used these GST-fusion proteins in binding assays to precipitate mGluR1a-CT-FL. Bound mGluR1a-CT proteins were visualized in the following Western blots with an antibody against mGluRla-CT. The N-terminal catalytic domain of CaMKII $\alpha$, GST-CaMKII $\alpha-$ CD(L91-S272), like GST-CaMKII $\alpha-F L(M 1-$ H478), precipitated mGluR1a-CT (Fig. $1 F$ ). The regulatory domain, GST-CaMKII $\alpha-\mathrm{RD}(\mathrm{H} 273-\mathrm{S} 314)$, and the C-terminal association domain, GST-CaMKII $\alpha-\mathrm{AD}(\mathrm{G} 315-\mathrm{H} 478)$, produced no precipitation. Moreover, GST-CaMKIV-FL did not precipitate mGluR1a-CT. Thus, CaMKII $\alpha-\mathrm{CD}$ seems to be the subdomain responsible for the mGluR1a interaction.

\section{$\mathrm{Ca}^{2+}$ and autophosphorylation enhance CaMKII $\alpha$ binding to mGluR1a}

$\mathrm{Ca}^{2+}$-activated CaM binds to the regulatory domain of CaMKII to activate the kinase. This activation usually regulates the affinity of CaMKII for its targets. To determine whether $\mathrm{Ca}^{2+}$ regulates the CaMKII binding to mGluRla, we tested the binding in the presence of $\mathrm{Ca}^{2+} / \mathrm{CaM}$. In the absence of $\mathrm{Ca}^{2+} / \mathrm{CaM}$ (with a $\mathrm{Ca}^{2+}$ chelator EGTA, $1 \mathrm{~mm}$ ), CaMKII $\alpha$ constitutively bound to mGluR1a-CT1 (Fig. 2A), similar to the results observed above. In the presence of $\mathrm{Ca}^{2+}(0.5 \mathrm{mM})$ and CaM $(1 \mu \mathrm{M})$, the CaMKII $\alpha$ binding was remarkably increased. This increase was attenuated by pretreatment with the L290-A309 fragment, a peptide that corresponds to the CaM binding domain of CaMKII and thereby competitively antagonizes the CaM binding to CaMKII (Colbran and Soderling, 1990) (Fig. 2B). These results demonstrate that, although there exists a detectable level of constitutive binding between CaMKII $\alpha$ and mGluRla, $\mathrm{Ca}^{2+} / \mathrm{CaM}$ further enhance the affinity of CaMKII $\alpha$ for mGluR1a.

Activated CaMKII $\alpha$ undergoes autophosphorylation at T286, which keeps the kinase active even after initial $\mathrm{Ca}^{2+}$ signals subside (Hudmon and Schulman, 2002). To determine the binding 
A mGluR1a-CT1(K841-T1000)

KPERNVRSAFTTSDVVRMHVGDGKLPCRSNTFLNIFRRKKPGAGNANSNGKSVSWSEPGGRQAPKGQHVWQRLSVHVKTNE
H859-K879
$\frac{\text { TACNQTAVIKPLTKSYQGSGKSLTFSDASTKTLYNVEEEDNTPSAHFS PPSSPSMVVHRRGPPVATTPPLPPHLTAEET }}{\text { N925-K942 } \frac{\text { K935-K952 }}{\text { A8 }}}$

B

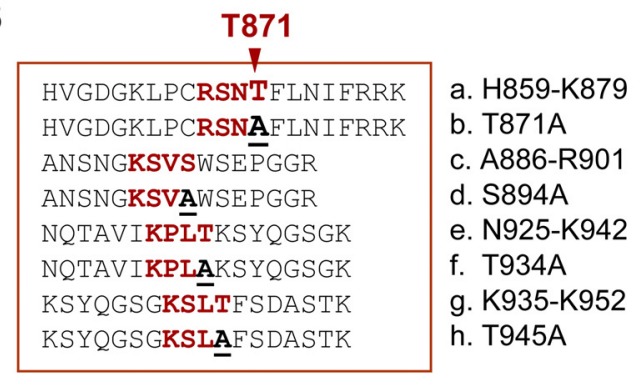

C

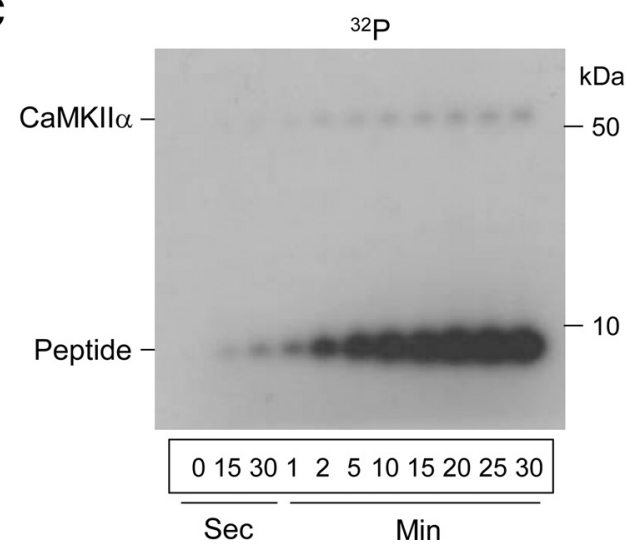



D

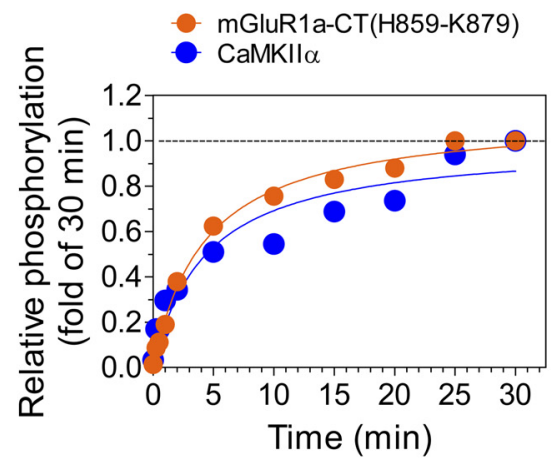

D PKA

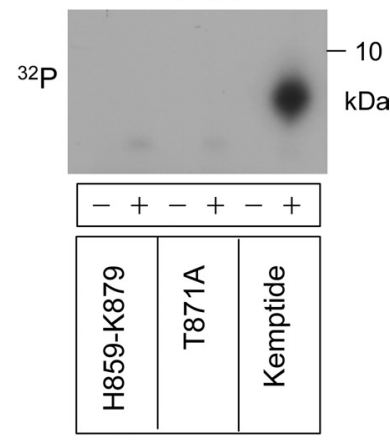

Figure 4. Phosphorylation of mGluR1a T871 by CaMKII $\alpha$. A, Analysis of amino acid sequence of entire mGluR1a-CT1(K841-T1000). Four fragments flanking the consensus CaMKII phosphorylation motif are underlined. $B$, Phosphorylation of synthetic peptides ( $a, c, e$, and g) and their corresponding mutants (b, $d$, $f$, and $h$ ). A representative autoradiograph is shown above the Coomassie Brilliant Blue (CBB) protein staining. Note that the H859-K879 peptide was markedly phosphorylated by CaMKIl $\alpha$. C, Time courses of mGluR1a-CT(H859-K879) phosphorylation and CaMKII $\alpha$ autophosphorylation. An autoradiograph is shown to the left of the quantified data. D, PKA-mediated phosphorylation of mGluR1a-CT(H859-K879) and kemptide. Note that PKA phosphorylated its classical substrate kemptide but not mGluR1a-CT(H859-K879). Phosphorylation reactions were performed at $30^{\circ} \mathrm{C}$ for 30 min with $\left[\gamma^{-}{ }^{32} \mathrm{P}\right] A T P$ in the presence of active PKA. The reactions were then subjected to gel electrophoresis, followed by autoradiography. Data are presented as means \pm SEM ( $n=3$ per group).

of autophosphorylated CaMKII $\alpha$ to mGluRla, we subjected CaMKII $\alpha$ to $\mathrm{Ca}^{2+} / \mathrm{CaM}$ activation and autophosphorylation in a reaction solution containing ATP (a preferred phosphate donor). We then used autophosphorylated CaMKII $\alpha$ in binding assays in the presence of EGTA ( $1 \mathrm{~mm})$. We found that autophosphorylated CaMKII $\alpha$ exhibited a higher level of binding to mGluRlaCT1 compared with unphosphorylated CaMKII $\alpha$ (Fig. 2C). Thus, T286 autophosphorylation sustains the kinase at a high level of binding to mGluRla.

\section{CaMKII $\alpha$ phosphorylates mGluR1a}

To determine whether CaMKII $\alpha$ phosphorylates mGluRla, we monitored the CaMKII $\alpha$-catalyzed incorporation of ${ }^{32} \mathrm{P}$ into mGluRla in sensitive autoradiography. Active CaMKII $\alpha$ in the presence of $\mathrm{Ca}^{2+} / \mathrm{CaM}$ strongly phosphorylated GSTmGluR1a-CT1 but not GST alone and GST-mGluR1a-CT2 (Fig. 3A). GST-mGluR1a-IL1 only showed much weaker phosphorylation. In assays with another glutamate receptor, i.e., the AMPA receptor, a known substrate of CaMKII (Barria et al., 1997; Mammen et al., 1997), we observed phosphorylation of the CT fragment of AMPA receptor GluA1 subunits (Fig. $3 A$ ), which served as a positive control. Inactive CaMKII $\alpha$ in the absence of
$\mathrm{Ca}^{2+} / \mathrm{CaM}$ did not phosphorylate mGluR1a-CT1 (Fig. 3B), neither did active CaMKII $\alpha$ in the absence of ATP (Fig. 3C). Dephosphorylation treatment of a duplicate reaction with CIP significantly reduced mGluR1a-CT1 phosphorylation (data not shown). These data identify mGluRla as a preferred substrate of CaMKII $\alpha$ and primary phosphorylation site(s) are restricted to CT1.

CT1 contains a total of four sites that are consistent with the consensus CaMKII phosphorylation sequence, $\mathrm{R} / \mathrm{KXXS} / \mathrm{T}$ (White et al., 1998) (Fig. 4A). We thus synthesized four peptides flanking these potential phosphorylation sites. Using these peptides together with their site-directed mutants, we performed a series of phosphorylation assays to identify accurate phosphoaccepting site(s) within CT1 (Fig. 4B). Interestingly, CaMKII $\alpha$ intensely phosphorylated only one peptide (H859-K879) (Fig. $4 B$ ). In contrast, CaMKII $\alpha$ produced little or no phosphorylation signals in other three peptides (A886-R901, N925-K942, and K935-K952). The positive H859-K879 peptide contains an $868-$ RSNT-871 motif that aligns well with the consensus sequence. When mutating threonine 871 (T871) to alanine (T871A), no phosphorylation was detected in the peptide. This complete loss of phosphorylation signals supports T871 as the primary site of 
A



B

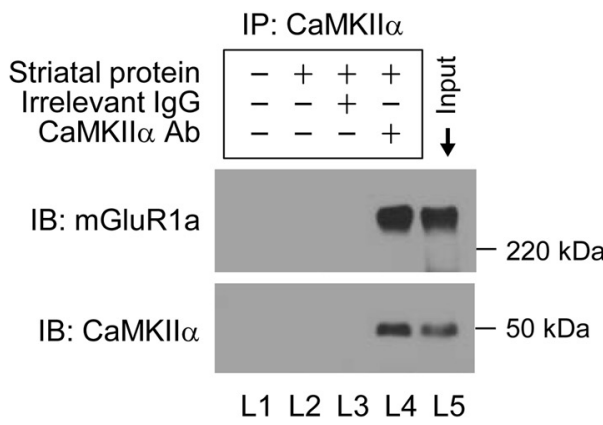

C

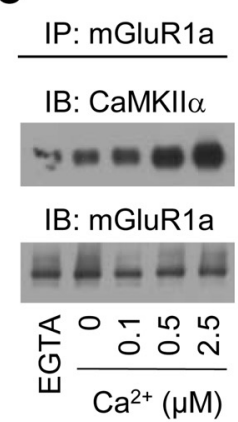

F

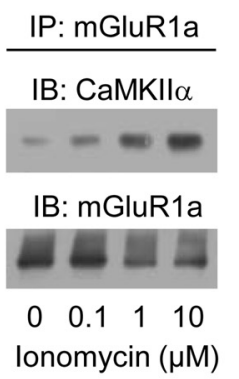

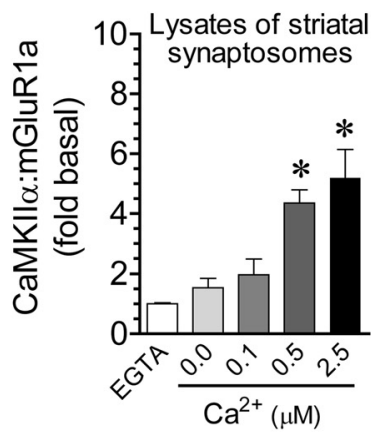

D

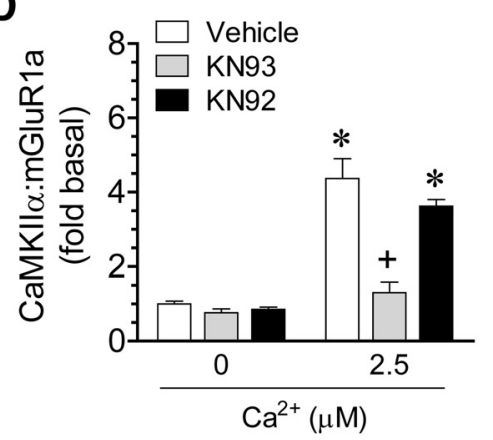

G

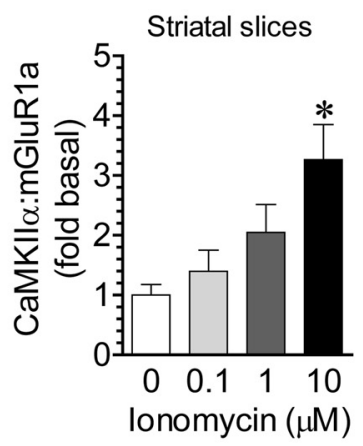

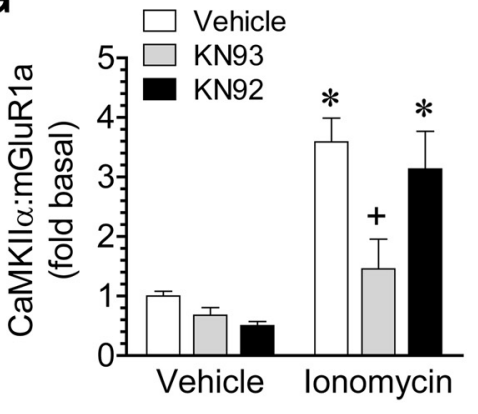

E

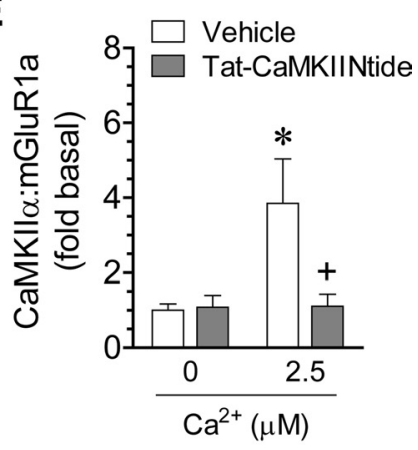

H

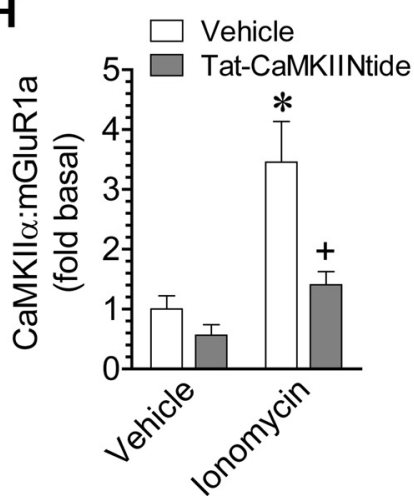

Figure 5. Interactions of CaMKII $\alpha$ with mGluR1a in striatal neurons. $A, B$, Coimmunoprecipitation (IP) of CaMKIl $\alpha$ and mGluR1a in rat striatal synaptosomes. Lanes 2 and 3 showed no specific bands because of the lack of a precipitating antibody (L2) and the use of an irrelevant $\operatorname{lgG}(\mathrm{L} 3)$. The input was 1 and $6 \%$ of total solubilized proteins used in the CaMKIl $\alpha$ and mGluR1a coimmunoprecipitation, respectively. C, Effects of $\mathrm{Ca}^{2+}(10 \mathrm{~min})$ on the association of CaMKIl $\alpha$ with mGluR1a. D, Effects of KN93 and KN92 on the Ca ${ }^{2+}$-stimulated CaMKIl $\alpha$-mGluR1a association. $\mathrm{Ca}^{2+}(2.5 \mu \mathrm{m})$ was cotreated with KN93 or KN92 $(20 \mu \mathrm{M})$ for $10 \mathrm{~min}$. E, Effects of Tat-CaMKIINtide on the Ca ${ }^{2+}$-stimulated CaMKIII $\alpha$-mGluR1a association. Tat-CaMKIINtide $(2 \mu \mathrm{m})$ was applied $45 \mathrm{~min}$ before and during $\mathrm{Ca}^{2+}(2.5 \mu \mathrm{m}, 10 \mathrm{~min}) . \boldsymbol{F}$, Effects of ionomycin (10 min) on the association of CaMKIl $\alpha$ with mGluR1a. G, Effects of KN93 and KN92 on the ionomycin-stimulated CaMKII $\alpha$-mGluR1a association. Ionomycin $(10 \mu \mathrm{m})$ was cotreated with KN93 or KN92 $(20 \mu \mathrm{m})$ for $10 \mathrm{~min}$. $\boldsymbol{H}$, Effects of Tat-CaMKIINtide on the ionomycin-stimulated CaMKIll $\alpha$-mGluR1a association. Tat-CaMKIINtide $(2 \mu \mathrm{M})$ was applied $45 \mathrm{~min}$ before and during ionomycin $(10 \mu \mathrm{m}, 10 \mathrm{~min})$. Lysates of striatal synaptosomes $(\boldsymbol{C}-\boldsymbol{E})$ or striatal slices $(\boldsymbol{F}-\boldsymbol{H})$ were used. Precipitated proteins were visualized by immunoblots (IB). Data are presented as means \pm SEM $\left(n=3-4\right.$ per group). ${ }^{*} p<0.05$ versus EGTA, vehicle, or vehicle + vehicle. ${ }^{+} p<0.05$ versus $\mathrm{Ca}^{2+}$ or vehicle + ionomycin.

phosphorylation within mGluR1a-CT1. Of note, T871 lies within the center of the CaMKII $\alpha$ binding motif in mGluRlaCT1. Additional studies that aimed to characterize T871 phosphorylation discovered that phosphorylation of T871-containing peptides was rapid and comparable with autophosphorylation of CaMKII $\alpha$ (Fig. 4C). No phosphorylation was seen in the H859K879 peptide in response to active PKA, whereas active PKA readily phosphorylated its classical substrate peptide, kemptide (Fig. 4D).

\section{Interactions of CaMKII $\alpha$ with mGluR1a in vivo}

We next wanted to examine the interaction between native CaMKII $\alpha$ and mGluRla in neurons in vivo. We thus performed coimmunoprecipitation with the solubilized synapto- somal fraction (P2) from the rat striatum. In the first set of coimmunoprecipitation with an anti-mGluRla antibody, a CaMKII $\alpha$-immunoreactive band was consistently seen in the mGluR1a precipitates (Fig. 5A). In reverse coimmunoprecipitation with a CaMKII $\alpha$ antibody, the mGluRla immunoreactivity was displayed in the CaMKII $\alpha$ precipitates (Fig. $5 B$ ). The irrelevant IgG did not precipitate either protein. Thus, there exists the interaction between CaMKII $\alpha$ and mGluRla in striatal neurons in vivo.

\section{$\mathrm{Ca}^{2+}$ enhances CaMKII $\alpha-$-mGluRla interactions in striatal neurons}

$\mathrm{Ca}^{2+}$ enhanced CaMKII $\alpha-$ mGluRla-CT1 binding in vitro. To determine whether this reflects the case in neurons, we evaluated 

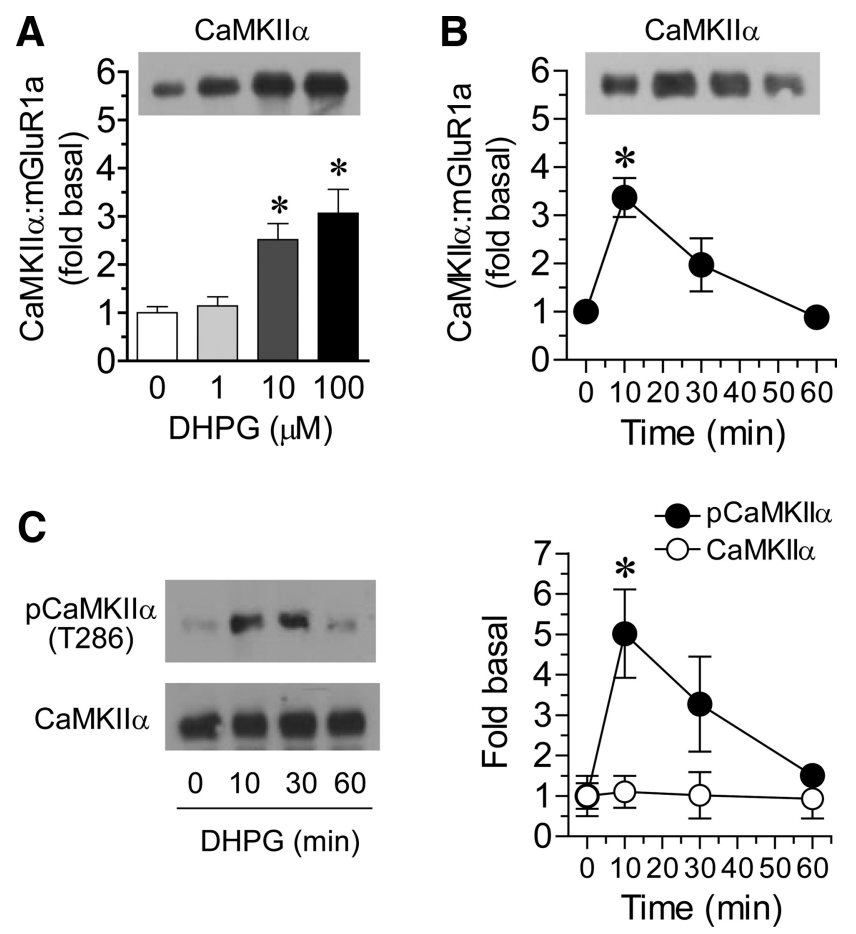

Figure 6. Effects of DHPG on CaMKIl $\alpha$-mGluR1a interactions in rat striatal neurons. $\boldsymbol{A}$, Concentration-dependent effects of DHPG (10 min) on CaMKII $\alpha$-mGluR1a interactions in striatal slices. $\boldsymbol{B}$, Time-dependent effects of DHPG $(100 \mu \mathrm{m})$ on CaMKIl $\alpha-$ mGluR1a interactions in striatal slices. $\boldsymbol{C}$, Time-dependent effects of DHPG $(100 \mu \mathrm{m})$ on cellular levels of pCaMKII $\alpha$ (T286) and CaMKII $\alpha$ in striatal slices. Proteins were visualized by immunoblots. Data are presented as means $\pm \operatorname{SEM}\left(n=3-5\right.$ per group). ${ }^{*} p<0.05$ versus basal levels.

the $\mathrm{Ca}^{2+}$-regulated interaction between the two endogenous proteins in rat striatal neurons using coimmunoprecipitation. Direct addition of $\mathrm{Ca}^{2+}$ to lysates of striatal synaptosomes (0.1$2.5 \mu \mathrm{M}, 10 \mathrm{~min}$ ) concentration-dependently elevated the amount of CaMKII $\alpha$ bound to mGluRla (Fig. $5 C$ ). This elevation seems to result from $\mathrm{Ca}^{2+}$ activation of CaMKII $\alpha$ because it was blocked by KN93 $(20 \mu \mathrm{M})$, an inhibitor that inhibits activation of CaMKII by preventing the CaM binding, but not by KN92, an inactive analogy of KN93 (Fig. 5D). Another cell-permeable and highly selective CaMKII inhibitory peptide, Tat-CaMKIINtide (Chang et al., 1998; Vest et al., 2007), incubated at $2 \mu \mathrm{M}$ (45 min before $\mathrm{Ca}^{2+}$ addition) also blocked the $\mathrm{Ca}^{2+}$-mediated elevation (Fig. $5 E$ ). These results demonstrate $\mathrm{Ca}^{2+}$-sensitive nature of interactions between native CaMKII $\alpha$ and mGluRla. To assay the interaction in living neurons, we subjected rat striatal slices to a $\mathrm{Ca}^{2+}$ ionophore, ionomycin. Like $\mathrm{Ca}^{2+}$ addition to lysates, applying ionomycin to slices $(0.1-10 \mu \mathrm{M}$, $10 \mathrm{~min}$ ) produced a concentration-dependent increase in CaMKII $\alpha-$ mGluR1a interactions (Fig. $5 F$ ). This increase was blocked by KN93 (Fig. 5G) and Tat-CaMKIINtide (Fig. 5H). Neither KN93 nor Tat-CaMKIINtide altered basal CaMKII $\alpha-$ mGluRla interactions. These results establish that $\mathrm{Ca}^{2+}$ augments CaMKII $\alpha-$ mGluRla interactions in striatal neurons.

Agonist-induced interactions between CaMKII and mGluR1a Activation of mGluR1 leads to intracellular $\mathrm{Ca}^{2+}$ release. To define whether activation of mGluR1 affects CaMKII $\alpha-$ mGluR1a interactions, we investigated pharmacological effects of the group I mGluR agonist DHPG on coimmunoprecipitation of CaMKII $\alpha$ and mGluRla. In rat striatal slices, applying DHPG (10 min) substantially increased the amount of CaMKII $\alpha$ coimmunoprecipitated with mGluR1a (Fig. 6A). The increase was evidently concentration dependent (Fig. 6A) and dynamic (Fig. 6B). The transient response reached peak at $10 \mathrm{~min}$ and gradually returned to the normal level by $60 \mathrm{~min}$ (Fig. $6 \mathrm{~B}$ ). Similar to this, corresponding increases in autophosphorylated CaMKII $\alpha$ levels were induced, whereas total cellular levels of CaMKII $\alpha$ remained stable (Fig. 6C). These data reveal a feedback interaction between CaMKII $\alpha$ and mGluR1a. In response to the agonist, CaMKII $\alpha$ was recruited to the activated receptor.

As aforementioned, CaMKII $\alpha$ binds to the membraneproximal CT region of mGluRla. To identify a sufficient binding motif from this region, we synthesized a 14 aa interfering peptide (KLPCRSNTFLNIFR, mGluR1a-i) flanking the T871 phosphorylation site. We then tested whether this peptide competes with mGluR1a-CT1 for binding to CaMKII $\alpha$. In binding assays in vitro, the peptide substantially blocked the binding of GSTmGluR1a-CT1 to CaMKII $\alpha$ (Fig. 7A). However, a sequencescrambled control peptide (SIFNRKNRCLPLFT, mGluRla-c) did not (Fig. 7A). Thus, a CT1 region corresponding to these 14 residues, including the $\mathrm{T} 871$ phosphorylation site, constitutes a core motif for CaMKII $\alpha$ binding. To determine the effect of these peptides in striatal neurons, we synthesized the interfering and control peptide together with Tat (YGRKKRRQRRR), an arginine-enriched domain known to render fusion peptides cell permeability (Aarts et al., 2002). Adding Tat-mGluR1a-i (10 $\mu \mathrm{M}$, 45 min before DHPG) to rat striatal slices significantly reduced the DHPG-induced interaction of CaMKII $\alpha$ with mGluR1a (Fig. $7 B$ ). In contrast, Tat-mGluRla-c had no effect (Fig. $7 B$ ). Thus, the mGluRla-i-sensitive site on mGluR1-CT is important for harboring CaMKII $\alpha$ binding.

\section{CaMKII desensitizes mGluRla}

The interaction of CaMKII $\alpha$ with mGluRla may have functional consequences. To clarify this, we investigated the functional role of CaMKII $\alpha$ in the regulation of mGluRla-associated signaling. Activation of $\mathrm{G} \alpha_{\mathrm{q}}$-coupled mGluRla is known to stimulate PLC $\beta 1$, which in turn hydrolyzes PI molecules to DAG and $\mathrm{IP}_{3}$ (Niswender and Conn, 2010; Traynelis et al., 2010). We thus measured the $\mathrm{IP}_{3}$ yield as the functional output of mGluR1a signaling. To this end, we used a fluorescence polarization tool to directly assay rapid rises in cytosolic $\mathrm{IP}_{3}$ in response to mGluR1a agonist stimulation. In rat striatal slices, applying DHPG at 100 $\mu \mathrm{M}$ for different durations $(5,10,20,30,60,120$, or $180 \mathrm{~s})$ produced a rapid and transient elevation of $\mathrm{IP}_{3}$ (Fig. $8 \mathrm{~A}$ ). A peak increase was observed at $\sim 20 \mathrm{~s}$ incubation of DHPG. Pretreatment of striatal slices with the mGluRla antagonist 3-MATIDA (10 $\mu \mathrm{M}, 30 \mathrm{~min}$ before DHPG) partially blocked the $\mathrm{IP}_{3}$ formation induced by DHPG (100 $\mu \mathrm{M}, 20 \mathrm{~s}$ ) (Fig. 8B). Similarly, the mGluR5 antagonist MTEP (10 $\mu \mathrm{M}, 30 \mathrm{~min}$ before DHPG) induced a partial decrease in $\mathrm{IP}_{3}$ responses (Fig. 8B). Copretreatment with both antagonists almost completely blocked the effect of DHPG (Fig. 8B). These data validate our $\mathrm{IP}_{3}$ assays as a sensitive method for measuring $\mathrm{IP}_{3}$ production in striatal neurons and establish a sufficient mGluRla component in mediating $\mathrm{IP}_{3}$ responses to DHPG. The effect of DHPG on $\mathrm{IP}_{3}$ formation was then analyzed in the presence of MTEP in the following experiments to selectively study the mGluR1a signaling.

Most GPCRs undergo feedback desensitization (i.e., agonistdependent) after prolonged or repeated agonist stimulation (Aronica et al., 1993; Gereau and Heinemann, 1998; Ferguson, 2001; Kelly et al., 2008). This process involves phosphorylation of the receptor by either second-messenger-dependent protein kinases (e.g., PKA, PKC, or CaMKII) or GPCR kinases. A number of previous studies have demonstrated desensitization of 


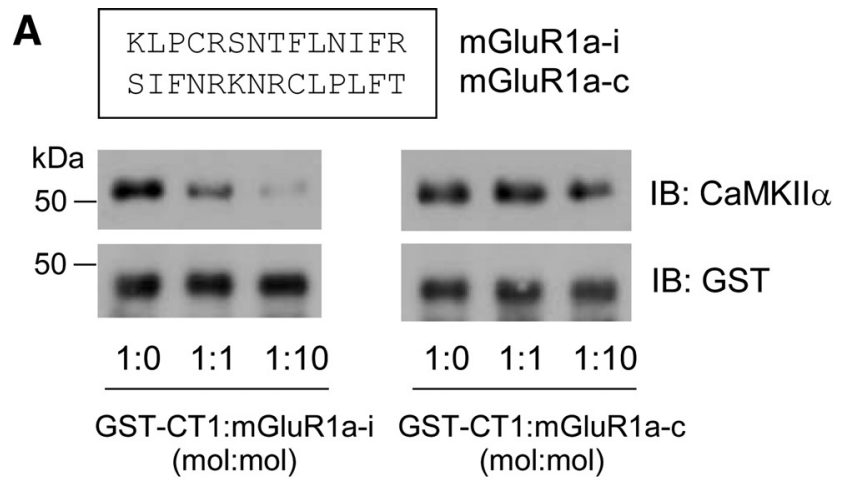

B

\begin{tabular}{|c|c|}
\hline Tat domain & mGluR1a-i/c \\
\cline { 1 - 1 } YGRKKRRQRRR-KLPCRSNTFLNIFR & Tat-mGluR1a-i \\
YGRKKRRQRRR-S I FNRKNRCLPLFT & Tat-mGluR1a-c \\
\hline
\end{tabular}
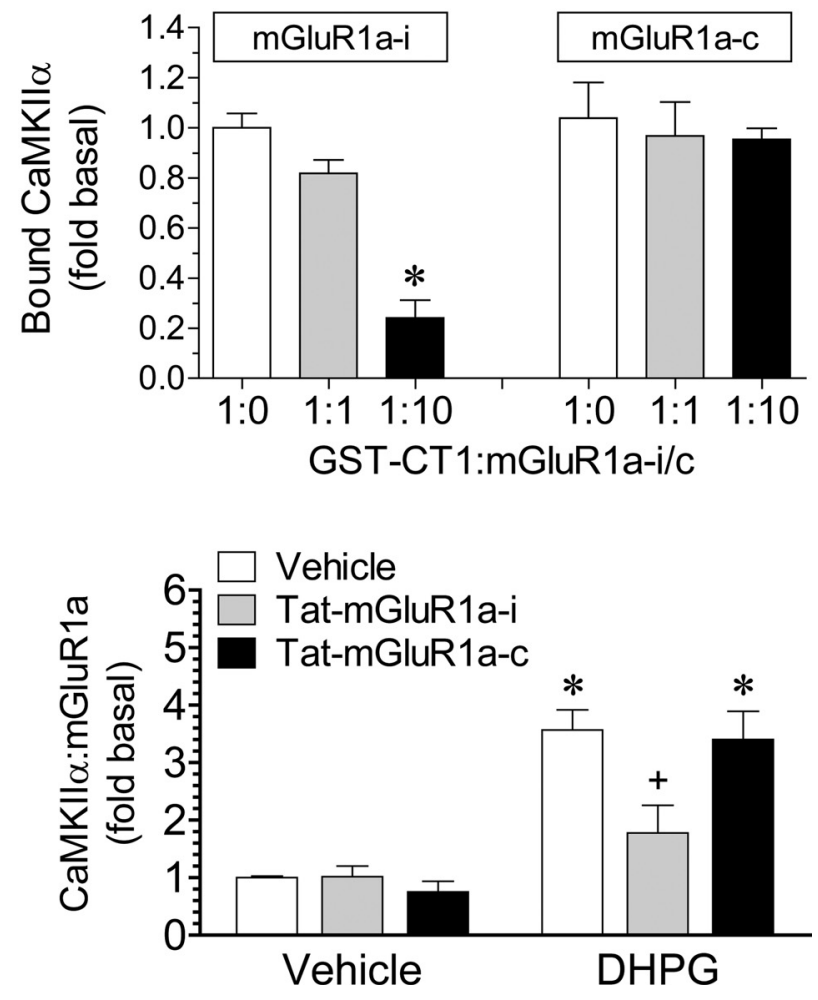

Figure 7. Effects of Tat peptides on CaMKII $\alpha$-mGluR1a interactions. $\boldsymbol{A}$, Effects of mGluR1a-i and mGluR1a-c on the in vitro binding of CaMKIl $\alpha$ to GST-mGluR1a-CT1. Representative immunoblots (IB) are shown to the left of the quantified data. $\boldsymbol{B}$, Effects of Tat-mGluR1a-i and Tat-mGluR1a-c on the DHPG-stimulated CaMKIl $\alpha-m G l u R 1 a$ association in striatal slices. Note that Tat-mGluR1a-i but not Tat-mGluR1a-c attenuated the DHPG-stimulated CaMKII $\alpha$-mGluR1a interaction. Tat peptides (10 $\mu \mathrm{m})$ were applied 45 min before and during DHPG (100 $\mu$ m, 10 min). Proteins were visualized by immunoblots. Data are presented as means \pm SEM ( $n=3-5$ per group). ${ }^{*} p<0.05$ versus basal levels. ${ }^{+} p<0.05$ versus vehicle + DHPG.

mGluR1 in response to agonist stimulation, although underlying mechanisms remain to be fully elucidated (Schoepp and Johnson, 1988; Thomsen et al., 1993; Alaluf et al., 1995; Herrero et al., 1998; Sato et al., 2004; Dhami and Ferguson, 2006). To determine whether CaMKII contributes to such feedback desensitization, we performed a set of pharmacological experiments in rat striatal slices. We first tested the occurrence of mGluR1 desensitization in terms of $\mathrm{IP}_{3}$ production. For this purpose, we subjected slices to a relatively prolonged preexposure (first treatment) to DHPG (100 $\mu \mathrm{M}, 5 \mathrm{~min}$ ) (Fig. 9A). We then washed off DHPG and inserted a 5 or 30 min interval before a challenge treatment (second treatment) with DHPG $(100 \mu \mathrm{M}) . \mathrm{IP}_{3}$ production was assayed at the peak, i.e., $20 \mathrm{~s}$ after the second addition of DHPG. At a $5 \mathrm{~min}$ internal, the second DHPG treatment produced typical $\mathrm{IP}_{3}$ responses in slices pretreated with vehicle (Fig. 9B). However, in slices preexposed to DHPG, the subsequent DHPG treatment failed to trigger a significant $\mathrm{IP}_{3}$ response, indicating the development of desensitization. When DHPG was given at a longer interval (30 min), substantial $\mathrm{IP}_{3}$ responses resumed (Fig. 9B), indicating a full recovery of desensitization. Remarkably, KN93 (20 $\mu \mathrm{M}, 30 \mathrm{~min}$ before and during the first DHPG treatment) significantly reversed the desensitized $\mathrm{IP}_{3}$ response to the second DHPG treatment (5 min after the first DHPG stimulation), whereas KN92 did not (Fig. 9C). This suggests that CaMKII inhibits mGluR1 activity and contributes to desensitization of the receptor. Like KN93, Tat-mGluR1a-i but not Tat-mGluR1a-c (10 $\mu \mathrm{M}, 45 \mathrm{~min}$ before and during the first DHPG stimulation) partially restored $\mathrm{IP}_{3}$ responses to the DHPG challenge (Fig. 9D). KN93, KN92, or Tat peptides alone had no effect on basal $\mathrm{IP}_{3}$ production (data not shown). These data support a model that CaMKII, through interacting with mGluR1, participates in form-
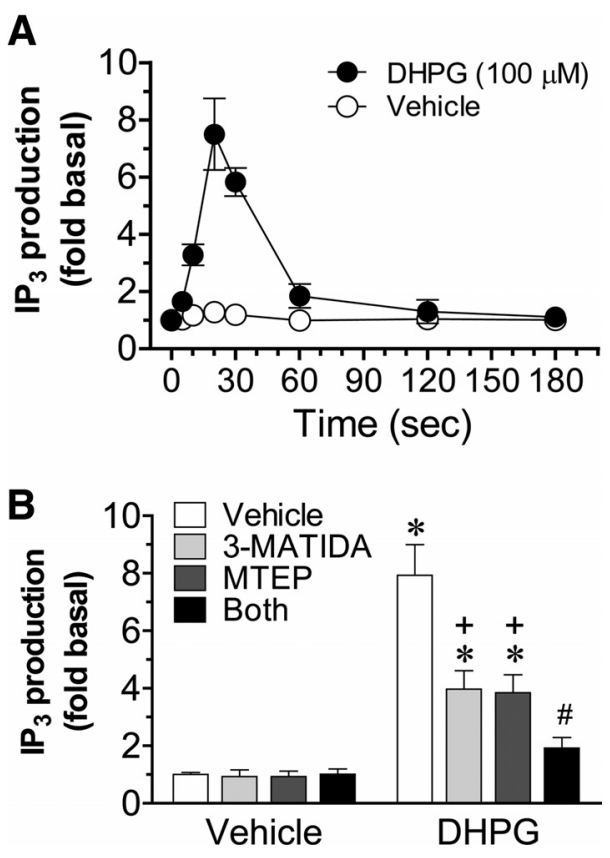

Figure 8. $\quad \mathbb{P}_{3}$ production after stimulation of $m G l u R 1 / 5$ in striatal neurons. $A$, Effects of DHPG (100 $\mu$ m for $5,10,20,30,60,120$, or 180 s) on cytosolic $\mathbb{P}_{3}$ levels. Note that the agonist triggered a rapidand transient production of $\mathbb{I}_{3}$. $\boldsymbol{B}$, Effects of the mGluR1 or 5 antagonist on the DHPG-stimulated $\mathbb{P}_{3}$ formation. Note that either antagonist alone partially blocked $I_{3}$ responses to DHPG, whereas coincubation of both antagonists additively blocked the $\mathrm{IP}_{3}$ production. Experiments were conducted on rat striatal slices. The antagonists (3-MATIDA and MTEP) were applied alone or together at $10 \mu \mathrm{m} 30$ min before and during 20 s incubation of DHPG $(100 \mu \mathrm{m})$. Data are presented as means $\pm \mathrm{SEM}(n=$ $3-5$ per group). ${ }^{*} p<0.05$ versus vehicle + vehicle. ${ }^{+} p<0.05$ versus vehicle + DHPG. ${ }^{\#} p<0.05$ versus 3-MATIDA + DHPG or MTEP + DHPG. 
ing a negative feedback loop controlling agonist-induced desensitization of the receptor.

\section{Discussion}

In this study, we investigated the proteinprotein interaction between CaMKII and mGluR1a and the regulation of mGluR1a by CaMKII via a phosphorylation mechanism in neurons. We found that CaMKII $\alpha$ directly bound to the mGluRla-CT. The affinity of CaMKII $\alpha$ for mGluRla was enhanced by $\mathrm{Ca}^{2+}$ in vitro. In striatal neurons, the mGluR1 agonist DHPG activated the $\mathrm{IP}_{3}-\mathrm{Ca}^{2+}$ pathway, which in turn activated CaMKII $\alpha$ and led to the recruitment of active CaMKII $\alpha$ to mGluRla. The direct association with CaMKII $\alpha$ implies that mGluRla may be a biochemical substrate of the enzyme. Indeed, CaMKII $\alpha$ phosphorylated mGluRla at a threonine site (T871) in the CT. Physiologically, the activity- and $\mathrm{Ca}^{2+}$-dependent interaction of CaMKII $\alpha$ with mGluRla forms a negative feedback loop critical for processing the agonist-induced desensitization of mGluRla.

Compared with other GPCR subfamilies, mGluRla has relatively small intracellular loops (IL1, IL2, and IL3) and a surprisingly large CT. This confers the $\mathrm{CT}$ as a primary site for protein-protein interactions. In fact, most mGluR1a interacting partners discovered so far interact with the CT (Enz, 2012; Fagni, 2012). Likewise, CaMKII $\alpha$ in this study bound to the mGluRla-CT. The binding of CaMKII $\alpha$ is isoform selective because another isoform, CaMKIV, did not show any binding to the receptor. Noticeably, the binding site in the mGluR1a-CT contains $\mathrm{R} / \mathrm{KXXS} / \mathrm{T}$ residues, a consensus substrate recognition motif for CaMKII (White et al., 1998). This $\mathrm{R} / \mathrm{KXXS} / \mathrm{T}$-containing binding region is conserved among long (1a) and short (1b, 1c, and 1d) variants of mGluR1 given the fact that all these common variants share the identical first 46 aa in the proximal CT. Another important characteristic of the CaMKII $\alpha-$ mGluRla binding is its $\mathrm{Ca}^{2+}$ sensitivity. Adding $\mathrm{Ca}^{2+}$ substantially enhanced the binding in vitro. $\mathrm{Ca}^{2+}$ also enhanced the association of endogenous CaMKII $\alpha$ with mGluRla in striatal neurons. Thus, $\mathrm{Ca}^{2+}$ positively regulates the interaction between the two proteins. The similar regulation has been seen in interactions of CaMKII $\alpha$ with other binding partners, including NMDA glutamate receptor NR2B subunits (Gardoni et al., 1998; Leonard et al., 1999), dopamine $\mathrm{D}_{3}$ receptors (Liu et al., 2009), muscarinic $\mathrm{M}_{4}$ receptors (Guo et al., 2010), and others (Colbran, 2004). Of note, $\mathrm{Ca}^{2+}$ sensitive CaM directly bound to the mGluR5-CT and competitively inhibited the binding of other proteins to mGluR5 (Minakami et al., 1997; Ishikawa et al., 1999; Lee et al., 2008; Wang et al., 2009). However, CaM did not bind to mGluR1 (Choi et al., 2011) and can therefore affect the CaMKII-mGluR1 interaction solely by its binding to CaMKII.

In addition to $\mathrm{Ca}^{2+}$, the autophosphorylation facilitates the binding of CaMKII $\alpha$ to mGluR1a. CaMKII $\alpha$ once activated phosphorylates its own phosphorylation site (T286) in addition to exogenous substrates. This autophosphorylation endows the kinase with
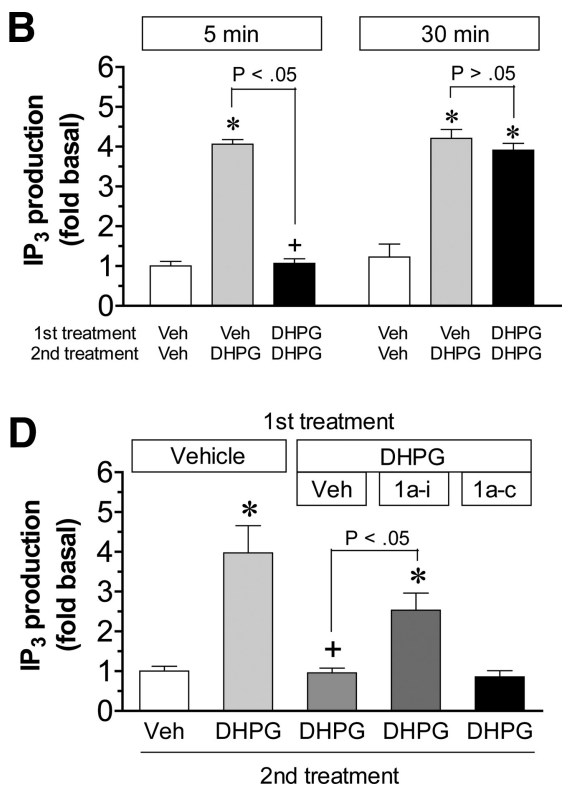

1st treatment

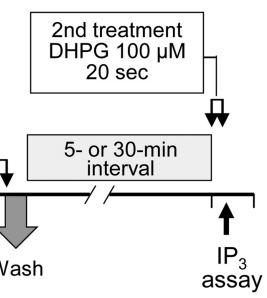

2nd treatment Veh DHPG DHPG Veh DHPG DHPG

2nd treatment

Figure 9. CaMKII desensitizes the mGluR1-mediated $\mathrm{IP}_{3}$ production in striatal neurons. $\boldsymbol{A}$, An agonist treatment paradigm DHPG treatment $(100 \mu \mathrm{m}, 20 \mathrm{~s})$ was assayed 5 min after the preexposure to DHPG $(\boldsymbol{C}, \boldsymbol{D})$. Data are presented as means $\pm \operatorname{SEM}(n=$ $3-6$ per group). ${ }^{*} p<0.05$ versus vehicle + vehicle. ${ }^{+} p<0.05$ versus vehicle + DHPG. Veh, Vehicle.

a $\mathrm{Ca}^{2+}$-independent (autonomous) activity (Hudmon and Schulman, 2002; Colbran and Brown, 2004). In this study, we found a high affinity of autophosphorylated CaMKII $\alpha$ for mGluRla. This is thought to be important for sustaining the interaction of the kinase with mGluRla and thus prolonging the regulation of receptor function after a transient $\mathrm{Ca}^{2+}$ response to agonist stimulation.

Phosphorylation serves as an important mechanism for modulating protein function. Phosphorylation of mGluR1 is therefore thought to have an impact on receptor physiology (Dhami and Ferguson, 2006; Kim et al., 2008; Mao et al., 2008; this study). Our functional assays show that the CaMKII inhibitor KN93 that blocked the binding of CaMKII $\alpha$ to mGluRla and presumably reduced the CaMKII-mediated phosphorylation of the receptor resensitized the receptor for its response to subsequent DHPG administration. Moreover, disrupting the CaMKII $\alpha-$ mGluRla association with an interaction-dead peptide (Tat-mGluRla-i) achieved the same result. Thus, CaMKII acts as a critical regulator in a feedback loop aimed to facilitate mGluR1 desensitization. This CaMKII-sensitive feedback model is in accordance with the early observations that (1) DHPG readily activated CaMKII in striatal and hippocampal neurons (Choe and Wang, 2001; Mockett et al., 2011), and (2) the internalization of mGluRla triggered homologously by glutamate required CaMKII activation (Mundell et al., 2004). The fact that the CaMKII binding and phosphorylation site (T871) in the mGluRla CT is immediately adjacent to the G-protein-coupling domain of mGluRla is noteworthy (Dhami and Ferguson, 2006).

The $\mathrm{Ca}^{2+}$ - and state-dependent nature of the CaMKIImGluR1 interaction may have an important functional consequence. Under basal conditions, CaMKII has a minimal influence over mGluR1 signaling, corresponding to a low level of interac- 
tive activity between CaMKII and the receptor. After ligand occupation, the mGluRla-associated $\mathrm{G} \alpha_{\mathrm{q}}-\mathrm{PLC}-\mathrm{IP}_{3}$ pathway is activated. This triggers a $\mathrm{Ca}^{2+}$ transient and subsequent activation of CaMKII. The activated kinase then interacts with and phosphorylates mGluR1a to facilitate the transition of receptors to a desensitized state. In this process, interference with the CaMKII-mGluR1a coupling by Tat-mGluR1a-i could remove the CaMKII-mediated desensitization and augment receptor responsiveness to agonist. Of note, mGluR1 activity is linked to synaptic plasticity. One classical form of synaptic plasticity, i.e., long-term depression (LTD), required selective activation of mGluR1 but not mGluR5 for its expression in corticostriatal glutamatergic synapses (Gubellini et al., 2001). Thus, it is intriguing to explore the role of CaMKII-mGluR1a interactions in striatal LTD in future studies.

The mGluRla has been demonstrated previously to be regulated by a phosphorylation mechanism involving PKC (Manzoni et al., 1990; Catania et al., 1991; Thomsen et al., 1993; Alaluf et al., 1995). Active PKC phosphorylated a consensus PKC phosphorylation site (T695) within the mGluR1a-IL2 in vitro (Medler and Bruch, 1999). This phosphorylation appears to mediate feedback desensitization of mGluR1 $\alpha$ in HEK293 cells (Francesconi and Duvoisin, 2000). Given a similar role of CaMKII $\alpha$ demonstrated in this study, PKC and CaMKII $\alpha$ may function in concert to orchestrate desensitization of the receptor.

\section{References}

Aarts M, Liu Y, Liu L, Besshoh S, Arundine M, Gurd JW, Wang YT, Salter MW, Tymianski M (2002) Treatment of ischemic brain damage by perturbing NMDA receptor-PSD-95 protein interactions. Science 298:846850. CrossRef Medline

AlalufS, Mulvihill ER, McIlhinney RA (1995) Rapid agonist mediated phosphorylation of the metabotropic glutamate receptor 1-alpha by protein kinase C in permanently transfected BHK cells. FEBS Lett 367:301-305. CrossRef Medline

Aronica E, Dell'Albani P, Condorelli DF, Nicoletti F, Hack N, Balázs R (1993) Mechanisms underlying developmental changes in the expression of metabotropic glutamate receptors in cultured cerebral granule cells: homologous desensitization and interactive effects involving $\mathrm{N}$-methylD-aspartate receptors. Mol Pharmacol 44:981-989. Medline

Barria A, Derkach V, Soderling T (1997) Identification of the $\mathrm{Ca}^{2+}$ / calmodulin-dependent protein kinase II regulatory phosphorylation site in the alpha-amino-3-hydroxyl-5-isoxazole-propionate-type glutamate receptor. J Biol Chem 272:32727-32730. CrossRef Medline

Catania MV, Aronica E, Sortino MA, Canonico PL, Nicoletti F (1991) Desensitization of metabotropic glutamate receptors in neuronal cultures. J Neurochem 56:1329-1335. CrossRef Medline

Chang BH, Mukherji S, Soderling TR (1998) Characterization of a calmodulin kinase II inhibitor protein in brain. Proc Natl Acad Sci U S A 95: 10890-10895. CrossRef Medline

Choe ES, Wang JQ (2001) Group I metabotropic glutamate receptors control phosphorylation of CREB, Elk-1 and ERK via a CaMKII-dependent pathway in rat striatum. Neurosci Lett 313:129-132. CrossRef Medline

Choi KY, Chung S, Roche KW (2011) Differential binding of calmodulin to group I metabotropic glutamate receptors regulates receptor trafficking and signaling. J Neurosci 31:5921-5930. CrossRef Medline

Colbran RJ (2004) Targeting of calcium/calmodulin-dependent protein kinase II. Biochem J 378:1-16. CrossRef Medline

Colbran RJ, Brown AM (2004) Calcium/calmodulin-dependent protein kinase II and synaptic plasticity. Curr Opin Neurobiol 14:318-327. CrossRef Medline

Colbran RJ, Soderling TR (1990) Calcium/calmodulin-independent autophosphorylation sites of calcium/calmodulin-dependent protein kinase II. Studies on the effect of phosphorylation of threonine 305/306 and serine 314 on calmodulin binding using synthetic peptides. J Biol Chem 265:11213-11219. Medline

Dhami GK, Ferguson SS (2006) Regulation of metabotropic glutamate receptor signaling, desensitization and endocytosis. Pharmacol Ther 111: 260-271. CrossRef Medline
Enz R (2007) The trick of the tail: protein-protein interactions of metabotropic glutamate receptors. Bioessays 29:60-73. CrossRef Medline

Enz R (2012) Metabotropic glutamate receptors and interacting proteins: evolving drug targets. Curr Drug Targets 13:145-156. CrossRef Medline

Fagni L (2012) Diversity of metabotropic glutamate receptor-interacting proteins and pathophysiological functions. Adv Exp Med Biol 970:63-79. CrossRef Medline

Ferguson SS (2001) Evolving concepts in G protein-coupled receptor endocytosis: the role in receptor desensitization and signaling. Pharmacol Rev 53:1-24. Medline

Francesconi A, Duvoisin RM (2000) Opposing effects of protein kinase C and protein kinase $\mathrm{A}$ on metabotropic glutamate receptor signaling: selective desensitization of the inositol triphosphate/ $\mathrm{Ca}^{2+}$ pathway by phosphorylation of the receptor-G protein-coupling domain. Proc Natl Acad Sci U S A 97:6185-6190. CrossRef Medline

Gardoni F, Caputi A, Cimino M, Pastorino L, Cattabeni F, Di Luca M (1998) Calcium/calmodulin-dependent protein kinase II is associated with NR2A/B subunits of NMDA receptor in postsynaptic densities. J Neurochem 71:1733-1741. CrossRef Medline

Gereau RW 4th, Heinemann SF (1998) Role of protein kinase C phosphorylation in rapid desensitization of metabotropic glutamate receptor 5 . Neuron 20:143-151. CrossRef Medline

Griffith LC (2004) Regulation of calcium/calmodulin-dependent protein kinase II activation by intramolecular and intermolecular interactions. J Neurosci 24:8394-8398. CrossRef Medline

Gubellini P, Saulle E, Centonze D, Bonsi P, Pisani A, Bernardi G, Conquet F, Calabresi P (2001) Selective involvement of mGlu1 receptors in corticostriatal LTD. Neuropharmacology 40:839-846. CrossRef Medline

Guo ML, Fibuch EE, Liu XY, Choe ES, Buch S, Mao LM, Wang JQ (2010) CaMKII $\alpha$ interacts with M4 muscarinic receptors to control receptor and psychomotor function. EMBO J 29:2070-2081. CrossRef Medline

Herrero I, Miras-Portugal MT, Sánchez-Prieto J (1998) Functional switch from facilitation to inhibition in the control of glutamate release by metabotropic glutamate receptors. J Biol Chem 273:1951-1958. CrossRef Medline

Hudmon A, Schulman H (2002) Neuronal $\mathrm{Ca}^{2+} /$ calmodulin-dependent protein kinase II: the role of structure and autoregulation in cellular function. Annu Rev Biochem 71:473-510. CrossRef Medline

Ishikawa K, Nash SR, Nishimune A, Neki A, Kaneko S, Nakanishi S (1999) Competitive interaction of seven in absentia homolog- $1 \mathrm{~A}$ and $\mathrm{Ca}^{2+} / \mathrm{cal}-$ modulin with the cytoplasmic tail of group 1 metabotropic glutamate receptors. Genes Cells 4:381-390. CrossRef Medline

Kelly E, Bailey CP, Henderson G (2008) Agonist-selective mechanisms of GPCR desensitization. Br J Pharmacol Suppl 1:S379-S388. CrossRef Medline

Kelly PT, McGuinness TL, Greengard P (1984) Evidence that the major postsynaptic density protein is a component of a $\mathrm{Ca}^{2+} /$ calmodulindependent protein kinase. Proc Natl Acad Sci U S A 81:945-949. CrossRef Medline

Kemp BE, Graves DJ, Benjamini E, Krebs EG (1977) Role of multiple basic residues in determining the substrate specificity of cyclic AMP-dependent protein kinase. J Biol Chem 252:4888-4894. Medline

Kennedy MB, Bennett MK, Erondu NE (1983) Biochemical and immunochemical evidence that the "major postsynaptic density protein" is a subunit of a calmodulin-dependent protein kinase. Proc Natl Acad Sci U S A 80:7357-7361. CrossRef Medline

Kim CH, Lee J, Lee JY, Roche KW (2008) Metabotropic glutamate receptors: phosphorylation and receptor signaling. J Neurosci Res 86:1-10. CrossRef Medline

Lee JH, Lee J, Choi KY, Hepp R, Lee JY, Lim MK, Chatani-Hinze M, Roche PA, Kim DG, Ahn YS, Kim CH, Roche KW (2008) Calmodulin dynamically regulates the trafficking of the metabotropic glutamate receptor mGluR5. Proc Natl Acad Sci U S A 105:12575-12580. CrossRef Medline

Leonard AS, Lim IA, Hemsworth DE, Horne MC, Hell JW (1999) Calcium/ calmodulin-dependent protein kinase II is associated with the $\mathrm{N}$-methylD-aspartate receptor. Proc Natl Acad Sci U S A 96:3239-3244. CrossRef Medline

Liu XY, Mao LM, Zhang GC, Papasian CJ, Fibuch EE, Lan HX, Zhou HF, Xu M, Wang JQ (2009) Activity-dependent modulation of limbic dopamine D3 receptors by CaMKII. Neuron 61:425-438. CrossRef Medline

Mammen AL, Kameyama K, Roche KW, Huganir RL (1997) Phosphorylation of the alpha-amino-3-hydroxy-5-methylisoxazole4-propionic acid 
receptor GluR1 subunit by calcium/calmodulin-dependent kinase II. J Biol Chem 272:32528-32533. CrossRef Medline

Manzoni OJ, Finiels-Marlier F, Sassetti I, Blockaert J, le Peuch C, Sladeczek FA (1990) The glutamate receptor of the Qp-type activates protein kinase $\mathrm{C}$ and is regulated by protein kinase C. Neurosci Lett 109:146-151. CrossRef Medline

Mao LM, Liu XY, Zhang GC, Chu XP, Fibuch EE, Wang LS, Liu Z, Wang JQ (2008) Phosphorylation of group I metabotropic glutamate receptors (mGluR1/5) in vitro and in vivo. Neuropharmacology 55:403-408. CrossRef Medline

Mao LM, Guo ML, Jin DZ, Fibuch EE, Choe ES, Wang JQ (2011) Posttranslational modification biology of glutamate receptors and drug addiction. Front Neuroanat 5:19. CrossRef Medline

Medler KF, Bruch RC (1999) Protein kinase $C \beta$ and $\delta$ selectively phosphorylate odorant and metabotropic glutamate receptors. Chem Senses 24: 295-299. CrossRef Medline

Miller SG, Kennedy MB (1986) Regulation of brain type II $\mathrm{Ca}^{2+}$ / calmodulin-dependent protein kinase by autophosphorylation: a $\mathrm{Ca}^{2+}$ triggered molecular switch. Cell 44:861-870. CrossRef Medline

Minakami R, Jinnai N, Sugiyama H (1997) Phosphorylation and calmodulin binding of the metabotropic glutamate receptor subtype 5 (mGluR5) are antagonistic in vitro. J Biol Chem 272:20291-20298. CrossRef Medline

Mockett BG, Guévremont D, Wutte M, Hulme SR, Williams JM, Abraham WC (2011) Calcium/calmodulin-dependent protein kinase II mediates group I metabotropic glutamate receptor-dependent protein synthesis and long-term depression in rat hippocampus. J Neurosci 31:7380-7391. CrossRef Medline

Mundell SJ, Pula G, McIlhinney RA, Roberts PJ, Kelly E (2004) Desensitization and internalization of metabotropic glutamate receptor la following activation of heterologous Gq/11-coupled receptors. Biochemistry 43: 7541-7551. CrossRef Medline

Nicoletti F, Bockaert J, Collingridge GL, Conn PJ, Ferraguti F, Schoepp DD, Wroblewski JT, Pin JP (2011) Metabotropic glutamate receptors: from the workbench to the bedside. Neuropharmacology 60:1017-1041. CrossRef Medline

Niswender CM, Conn PJ (2010) Metabotropic glutamate receptors: physiology, pharmacology, and disease. Annu Rev Pharmacol Toxicol 50:295-322. CrossRef Medline
Sato M, Tabata T, Hashimoto K, Nakamura K, Nakao K, Katsuki M, Kitano J, Moriyoshi K, Kano M, Nakanishi S (2004) Altered agonist sensitivity and desensitization of neuronal mGluR1 responses in knock-in mice by a single amino acid substitution at the PKC phosphorylation site. Eur J Neurosci 20:947-955. CrossRef Medline

Schoepp DD, Johnson BG (1988) Selective inhibition of excitatory amino acid-stimulated phosphoinositide hydrolysis in the rat hippocampus by activation of protein kinase C. Biochem Pharmacol 37:4299-4305. CrossRef Medline

Schwarze SR, Ho A, Vocero-Akbani A, Dowdy SF (1999) In vivo protein transduction: delivery of a biologically active protein into the mouse. Science 285:1569-1572. CrossRef Medline

Tallaksen-Greene SJ, Kaatz KW, Romano C, Albin RL (1998) Localization of mGluRla-like immunoreactivity and mGluR5a-like immunoreactivity in identified population of striatal neurons. Brain Res 780:210-217. CrossRef Medline

Testa CM, Standaert DG, Young AB, Penney JB Jr (1994) Metabotropic glutamate receptor mRNA expression in the basal ganglia of the rat. J Neurosci 14:3005-3018. Medline

Thomsen C, Mulvihill ER, Haldeman B, Pickering DS, Hampson DR, Suzdak PD (1993) A pharmacological characterization of the mGluR $1 \alpha$ subtype of the metabotropic glutamate receptor expressed in a cloned baby hamster kidney cell line. Brain Res 619:22-28. CrossRef Medline

Traynelis SF, Wollmuth LP, McBain CJ, Menniti FS, Vance KM, Ogden KK, Hansen KB, Yuan H, Myers SJ, Dingledine R (2010) Glutamate receptor ion channels: structure, regulation, and function. Pharmacol Rev 62:405-496. CrossRef Medline

Vest RS, Davies KD, O’Leary H, Port JD, Bayer KU (2007) Dual mechanism of a natural CaMKII inhibitor. Mol Biol Cell 18:5024-5033. CrossRef Medline

Wang H, Westin L, Nong Y, Birnbaum S, Bendor J, Brismar H, Nestler E, Aperia A, Flajolet M, Greengard P (2009) Norbin is an endogenous regulator of metabotropic glutamate receptor 5 signaling. Science 326 : 1554-1557. CrossRef Medline

White RR, Kwon YG, Taing M, Lawrence DS, Edelman AM (1998) Definition of optimal substrate recognition motifs of $\mathrm{Ca}^{2+}$-calmodulindependent protein kinases IV and II reveals shared and distinctive features. J Biol Chem 273:3166-3172. CrossRef Medline 